\title{
Evaluation of Brazilian Children's Picture Books on Sexual Abuse Prevention according to Literature Criteria
}

\author{
Sheila Maria Prado Soma ${ }^{1}$ \\ Lúcia Cavalcanti de Albuquerque Williams \\ Programa de Pós-Graduação da Universidade Federal de São Carlos, \\ São Carlos, SP, Brazil
}

\begin{abstract}
There are many children's picture books addressing the topic of child sexual abuse. Such books are expected to have the potential of raising children's awareness on sexual abuse prevention. This paper evaluates children's picture books published in Brazil through an online questionnaire based on 27 criteria proposed in previous international studies. These criteria have the purpose of identifying features and/or issues that should be addressed in books that target sexual abuse prevention for children. Six books were selected and analysed by professionals from the area who completed an online assessment questionnaire. All selected books indicated potential for child sexual abuse prevention. Although none of the books presented all the criteria analysed, one stood out meeting $48 \%$ of the criteria. The results are discussed in terms of the recommended criteria, and according to specialists' agreement regarding the implementation potential of intervention strategies with young children.
\end{abstract}

Keywords: Child sexual abuse prevention, child sexual abuse and children's books.

\section{Avaliação de Livros Infantis Brasileiros sobre Prevenção de Abuso Sexual baseada em Critérios da Literatura}

\section{Resumo}

Há diversos livros para crianças que abordam o tema do abuso sexual infantil. Espera-se que tais livros tenham o potencial para aumentar a conscientização das mesmas a respeito dessa temática. O presente estudo avaliou livros infantis publicados por autores brasileiros, por meio de um questionário online baseado em 27 critérios propostos em estudos prévios internacionais. Tais critérios têm a finalidade de identificar características e/ou assuntos que devem ser abordados em livros que tratam do abuso sexual direcionados para o público infantil. Foram identificados seis livros e os mesmos foram disponibilizados para análise de juízes especialistas juntamente com o questionário de avaliação online. As avaliações indicaram que todos os livros selecionados apresentam potencial para prevenção do abuso sexual infantil. Embora nenhum dos livros tenha preenchido todos os critérios analisados, um deles se destacou com $48 \%$ critérios preenchidos. Os resultados são discutidos com base nos critérios apontados, bem como de acordo com a correspondência dos juízes, tendo em vista a aplicação potencial de estratégias de intervenção para crianças.

Palavras chave: Prevenção do abuso sexual infantil, violência sexual infantil e livros infantis.

Mailing address: Rua Javari, 4943, casa 12, Ribeirão Preto, SP, Brazil. Fone: 16 99754-4277. E-mail: Sheila. soma@yahoo.com.br

Apoio financeiro: Fundação de Amparo à Pesquisa do Estado de São Paulo (FAPESP; processo 2014/09582-5). 


\section{Evaluación de Libros Infantiles Brasileños de Prevención de Abuso Sexual a través de Criterios de la Literatura}

\section{Resumen}

Hay varios libros infantiles que abordan el tema del abuso sexual infantil. Se espera que estos libros tienen el potencial de aumentar la conciencia de los niños sobre este tema. Este estudio evaluó los libros infantiles publicados por autores brasileños, a través de un cuestionario en línea con base en 27 criterios propuestos en estudios anteriores para identificar las características y / o cuestiones que deben abordarse en un libro sobre el abuso sexual infantil. Seis libros han sido identificados y puestos a disposición para su análisis por parte de jueces expertos usando un cuestionario de evaluación en línea. Todos los libros seleccionados indicaron potencial para la prevención del abuso sexual infantil. Ninguno de los libros se ha completado todos los criterios analizados, pero uno se destacó con $48 \%$ de los criterios atendidos. Los resultados se discuten sobre la base de criterios indicados en vista de la aplicación potencial de las estrategias de intervención para los niños.

Palabras clave: Prevención del abuso sexual infantil, el abuso sexual infantil y libros para niños.

The prevention of child sexual abuse has increasingly become a research topic among scholars and professionals, which has contributed to the creation of prevention programs aiming primarily at enabling children to protect themselves against violence (Brino \& Williams, 2008; Padilha \& Williams, 2009; Vélez, Henao, Ordoñes, \& Gómez, 2015; Wolfe, 2006; Wurtele, 2008). Preventive programs make use of many resources to teach protective skills to children, among these are films, games, manuals and books for teachers, parents and children. However, there is a shortage of studies and research that evaluate these preventive strategies, confirming their effectiveness (Finkelhor, 1991; Kenny \&Wurtele, 2010).

Children enjoy stories and narratives through which they can feel connected to different plots and characters. Therefore, books are an important vehicle to promote emotional development in children by supplying storylines that allow them to be in touch with their own feelings, helping to experience these more clearly in an attempt to understand the world and their own reality (Caldin, 2002; Souza \& Bernardino, 2011).

Stories from books allow children to express themselves spontaneously, as they are invited to talk about themselves in the third person. It is possible to obtain important information from children depending on the degree in which they identify themselves as being part of the story (Caldin, 2002; Souto-Maior, 2000). What renders books with preventive plots so essential is the fact that they have the potential to help children who are experiencing problems, such as sexual abuse (Soma \& Williams, 2014).

Alves and Emmel (2008) conducted a study with three children and their caregivers referred to child protection services in São Paulo State, describing the impact on children and their mothers of fairy tales as emotional content facilitators. Through verbal reports collected after the interventions with the stories, the researchers observed the emergence of participants' daily life contents, in addition to comments about conflicts which could put their development at risk. Based on the results, it was concluded that the interventions with stories revealed important information on participants' personal experiences, including the abuse experienced, which stresses the importance of such interventions in helping children atribute new meaning to their personal history (Alves \& Emmel, 2008).

In another study aimed at developing strategies to improve cognitive, expressive and psychomotor skills, through storytelling, in 12 vulnerable children (Cunha et al., 2015) concluded that the stories in books are facilitators to promote discussions regarding children's daily lives and the violent contents experienced. The stories were triggers for researchers to discuss confron- 
tation strategies deriving from actions based on respect for others, as well as other nonviolent strategies.

There are two fundamental aspects that determine whether the plot of a book will engage the child's attention. The first one is that the story should capture the reader's attention, and the second is that it should be able to transport the reader into the story (Zak, 2013). This is only possible because, intuitively, we take interest in stories in which we realize that just as the characters, we too could be found in similar situations. Thus, paying attention to the story is a way of developing the ability to solve problems similar to those that the characters face (Cunha et al., 2015; McDaniel, 2001; Zak, 2013).

Based on the assumption that readers become part of the book being read, it may be suggested that, while interpreting the text, readers imprint a little about themselves when trying to understand their dilemmas. At this point they become co-authors of the story, complying or not with the writer's intentions (Caldin, 2002). When addressing a child reader, it is important to point out that they have not yet fully developed their critical capacity, or the ability to fully interpret the text. For this reason, the child is more susceptible to ideologies within texts or illustrations, and this factor should be of concern when taking into account the quality of materials directed at children, especially those covering complex topics, such as sexual abuse (Caldin, 2002; McDaniel, 2001; Souza \& Bernardino, 2011).

There are several types of Children's Picture Books for Prevention (CPBPs) on child sexual abuse (Soma \& Williams, 2014). These books are expected to have the potential to increase children's awareness to this subject. However, Soma and Williams (2014) identified only three international studies that assessed these books through established criteria to verify which were more suitable to be offered for children (Lampert, 2011; Lampert \& Walsh, 2010; McDaniel, 2001). Based on searches conducted in Brazilian literature databases, no records were found of research evaluating PCPBs on sexual abuse. Thus, this article aims to evaluate PCPBs published by
Brazilian authors, based on criteria proposed by the literature reviewed by Soma and Williams (2014).

\section{Method}

\section{Instrument}

Criteria for CPBPs Assessment - Children's Picture Books for Prevention (CCA). To achieve the objective proposed in this study, an assessment tool was designed, entitled "Criteria for CPBPs (Children's Picture Books for Prevention) Assessment", henceforth referred to as CCA. This instrument relies on 27 criteria contemplated in the international literature, which should be present in CPBPs' contents to promote self-protective skills in children. The CCA was based on evaluation criteria described in the study conducted by Lampert and Walsh (2010), McDaniel (2001), and Rudman (1995 cited by McDaniel, 2001), as described in the study by Soma and Williams (2014). For the creation of the CCA, content analysis of each category of criteria was initially done to remove duplications. Thus, from a total of 31 criteria, 27 were selected to compose the instrument, followed by an open-ended question for evaluators to express their personal opinion regarding the PCPB analysed.

\section{Materials}

Children's Picture Books for Prevention (CPBPs). To accommodate this study's objective, the following books were selected for analysis:

1. Antônio (Ferreira, 2012), tells the story of a seven year old boy who liked to play, and was fond of memory games and comic books. Antonio had many dreams and would often visit his grandparents on holidays. However, his behavior began to change and the boy became aggressive and depressed. A large hand would always appear, and he did not like it because it grasped him, ordering him to do whatever it wanted and keeping him from disclosing what afflicted him. The hand belonged to a family friend who often visited the boy's home. Antônio became ill 
and saw a doctor and a psychologist, but he could not tell anyone what was wrong because the hand would threaten him. As a result, Antonio cried whenever the hand appeared. That was when Olga, Antonio's caretaker, realized what was happening and protected him from the hand, as did his parents, putting an end to his suffering.

2. Chapeuzinho Cor de Rosa e a Astúcia do Lobo Mau ([Little Pink Riding Hood and the Big Bad Wolf's Shrewdness], Siquinel, 2010), tells the story of Little Pink Riding Hood who, while going to visit her grandmother, meets the Big Bad Wolf along the way and the two become friends. Riding Hood and the Wolf begin to meet whenever she visits her grandmother, until one day he caresses her body in a way that makes her feel uncomfortable, asking her to keep it a secret. Her grandmother notices a shift in her behavior and Riding Hood reveals what happened. Grandmother seeks help and the Big Bad Wolf is arrested. The book features a preface with information for adults about sexual abuse, and, at the end, information on affetionate touching and body ownership for children and adults.

\section{A Invasão do Planeta chamado Carinho} ([The Invasion of a Planet called Affection], Fonseca, 2008), tells the story of two planets, Affection and Desire. On planet Affection all touches were good and on planet Desire all wishes were fulfilled. One day, planet Desire faced a great battle in which the good wishes banned the bad ones, who then went to planet Affection. There, they began to influence the inhabitants and, where there were only good touches, bad touches also appeared, confusing children. With time, the bad touches gave up living on planet Affection and took a rocket towards Earth, contaminating even those who were meant to protect children. The point of the story is that it is important to keep distance from these offenders who one day shall too be expelled from Earth.

4. Segredo Segredissimo ([The very Secretive Secret], Barros, 2011) shares the story of two best friends, Alice and Adriana. Alice was smart and clever, and the two friends were confidants. One day Adriana told Alice a very secretive secret: she said her uncle was not so nice and wanted to play adult games with her. Adriana was always sad and afraid every time her uncle showed up. Alice soon understood what was happening and encouraged her friend to share the secret with her mother, and that is what Adriana did. Her mother caringly listened to her, understanding her sadness. From that day on the uncle did not play adult games with her, and the two friends were no longer fearful. At the end, the book offers a quiz game for the children about the story.

5. O Segredo de Tartanina ([Tartanina's Secret], Silva, Soma, \& Watarai, 2011), has as co-author the first author of the present study. The book narrates the story of Tartanina, a happy and cheerful little turtle. After a while, her friends began to find Tartanina's behavior odd. She no longer wanted to play, and she carried a chest which became heavier every day. Glub, a little fish, then decided to follow his friend and discovered that Malvo, the octopus, took pictures of Tartanina without her shell on. Mr. Malvo threatened Glub and Tartanina, giving them sweets and toys. However, they were not happy - they were afraid and ashamed. Tartanina, who could not stand what was happening any longer, decides to disclose to her teacher what was happening. The teacher, in turn, calls the protection services in search of help, and the victimization comes to an end. Malvo, the octopus is charged, and as a result has to learn how to relate to children in a healthy way. The book is interactive, allowing children to participate in the story. It provides information for parents in the preface and an Adult's Guide with complementary activities, as support for prevention with children's groups.

6. The book Pipo e Fifi (Arcari, 2013) tells the story of two little monsters who are brothers (Pipo and Fifi). Using gentle rhymes, the author begins the story pre- 
senting information on body anatomy and body ownership. Throughout the book, Fifi introduces readers to the Yes Touch, which are nice touches not causing discomfort, while Pipo presents the No Touch, those that make children confused, scared and uncomfortable. Later, Pipo and Fifi talk about body ownership, stating that children can say no to touches that make them feel uncomfortable. Pipo and Fifi know a trustworthy person, their teacher Sophia. They encourage children to disclose No Touches to someone they trust, and mention Child Protection services. The book is interactive, and it is available online, including a range of activities and guidelines to parents, teachers and children on its website.

\section{Participants}

Eighteen researchers in the area of child sexual abuse were invited to participate in the study as expert evaluators, of which 12 agreed to take part. The evaluators were psychologists holding at least a Master Degree, and were at the time of the evaluations associated with Universities in the South, Southeast and Northeast regions of Brazil, as Professors or Graduate students.

\section{Procedure}

An online search was performed in Brazilian sales websites for CPBPs having child sexual abuse as a central theme. This search was guided by the keywords "child sexual abuse", "child sexual violence" and "children's picture books". The selection used the following inclusion criteria: (a) children's books available for sale online; (b) written by Brazilian authors; (c) dealing exclusively with child sexual abuse issues; and (d) published between January 2000 and July 2015 . This search resulted in the six books previously mentioned, which from now on will be identified by the letters: (A) Ferreira (2012); (B) Siquinel (2010); (C) Fonseca (2008); (D) Barros (2011); (E) Silva et al. (2011); and (F) Arcari (2013).

The books were initially purchased by the present researchers and transformed into PDF electronic documents (Portable Document Format). They were, then, inserted into an online platform (Google Docs), along with the assessment tool (CCA). These documents were sent to the evaluators via e-mail with the inclusion of information regarding the present study and instructions on how to complete the assessment tool. An individual link was provided with access to the respective PDF document (only one book per evaluator), and the CCA. Through random assignment, two evaluators were selected to assess each title. As soon as the evaluators finished their task, they received an e-mail informing that the PDF material previously available on the website was blocked, and thus unable to be saved.

\section{Data Analysis}

For the data analysis, descriptive and correlational statistics were used among the evaluators' responses. Questions contained in the questionnaire were grouped by theme similarity, based on the three skills described by Wurtele (2008). This author states that, to achieve efficiency in child sexual abuse prevention, a child must learn three main skills: (a) to recognize potentially abusive situations or potential abusers; (b) to try to resist by saying "no" and removing themselves from the potential perpetrator; and (c) to report previous or ongoing abuse to an authority figure. Among the 27 criteria of the CCA, 17 correspond to the ability to Recognize, 4 correspond to the ability to Resist, 3 to the ability to Report and 3 correspond to features that do not fit in the previously described skills. Book evaluations were carried out based on a scale of three levels, in which: (a) Y (Yes, meets the criteria) whether the book presents the information in an appropriate way; (b) $\mathrm{P}$ (partially meets the criteria) whether the book presents the information, but requires adjustments; and (c) N (Does not meet the criteria) if the book does not have the information, or if it is inserted improperly.

\section{Results}

The Kappa statistic was used for the quantitative analysis evaluators' agreement degree. To 
this end, the Kappa values considered were equal to or less than 0 (if $\mathrm{K}=0$ and $\mathrm{K}<0$ ), indicating a null agreement among evaluators; greater than 0 and near $1(\mathrm{~K}=0$ and $\mathrm{K}<0)$, indicating greater agreement than chance, and Kappa equal to 1 (K $=1)$, indicating that there is complete agreement among evaluators (Kraska-Miller, 2008).

Table 1

Evaluator Agreement Results (Kappa)

\begin{tabular}{ccccc}
\hline BOOK & $\mathrm{Y}$ & $\mathrm{N}$ & $\mathrm{P}$ & Total \\
\hline A & 0.216 & 0.419 & -0.114 & 0.185 \\
B & 0.25 & 0.341 & 0.308 & 0.313 \\
C & -0.063 & 0.154 & -0.038 & 0.038 \\
D & & & - & \\
E & 0.485 & 0.335 & 0.294 & 0.384 \\
F & 0.211 & 0.276 & -0.244 & 0.056 \\
\hline
\end{tabular}

Note. $\mathrm{Y}=$ Meets criterion; $\mathrm{N}=$ Dose not meet criterion; $\mathrm{P}=$ Partially meets criterion.

Table 1 shows that book E presented a higher level of agreement (kappa 0.485) among evaluators for the $\mathrm{Y}$ categories (criteria met). In regards to category $\mathrm{N}$ (criteria not met), book A had the highest rate of agreement (kappa 4.19), and for category P (partially met criteria), the highest agreement was found in regards to book B (kappa 0.313). In the case of book D, the value of Kappa was unable to be calculated, as no agreement was observed among evaluators for the $\mathrm{Y}$ category, thereby precluding analysis. By observing the negative values in Table 1 , it can be inferred that the agreement between evaluators was considered null, that is, the two evaluators produced opposite rankings for that particular category. Such was the case for category $P$ for book A (- 0.114); category Y (- 0.063) and $P$ (- 0.038) for book C; and category P (-0.244) for book F. By observing the general Kappa values, book $\mathrm{E}$ achieved the highest degree of agreement among evaluators (Kappa 0.384).

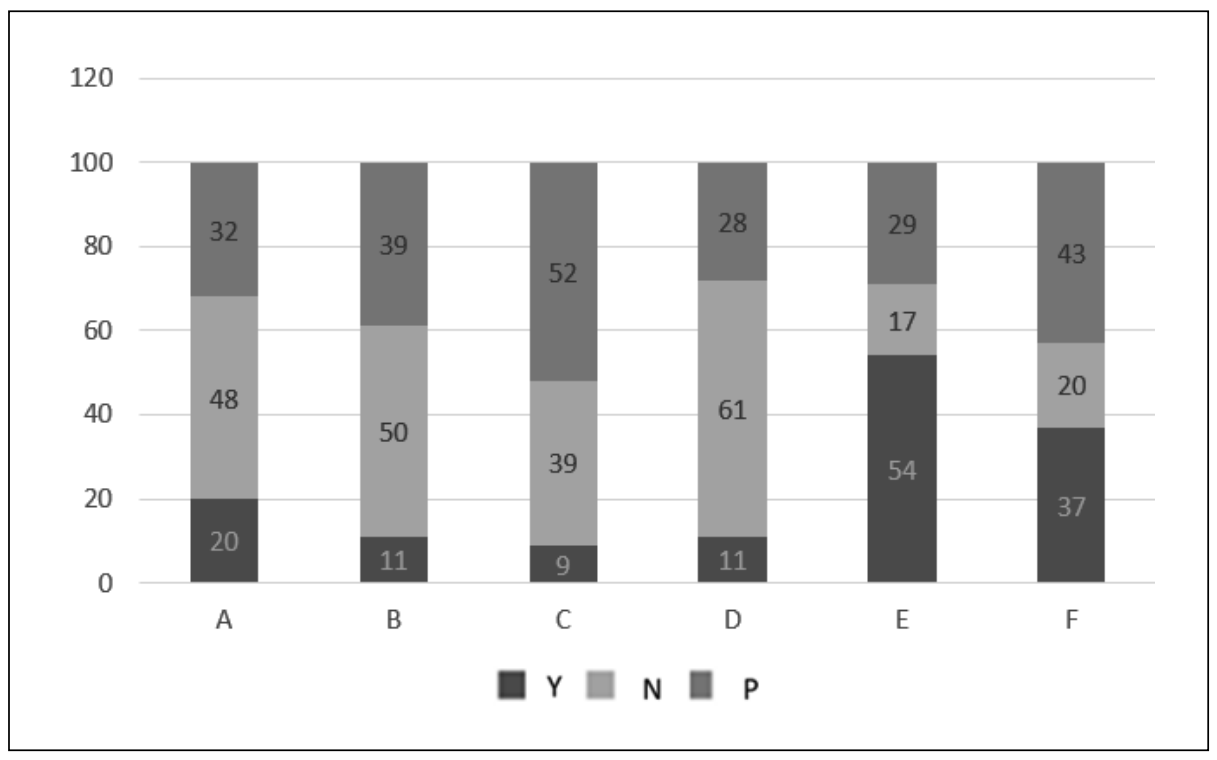

Figure 1. Frequency of criteria met $(Y)$, not met $(N)$ and partially met $(P)$. 
In terms of the three skills proposed by Wurtele (2008), as seen in Figure 1, of the 17 criteria listed under the ability to Recognize, the CPBPs $\mathrm{E}$ and $\mathrm{F}$ obtained the best performance levels, reaching over $70 \%$ of criteria and partially met criteria ( $79 \%$ and $70.5 \%$, respectively). In regards to the four criteria related to the ability to Resist, the CPBPs with superior performance were B, D, E and F (books B, D and E presented $75 \%$ of the "met fully" or "partially" criteria, and book $\mathrm{F}$ reached $87.5 \%$ ). For the three criteria regarding the ability to Report, the best performances (100\% of met criteria) were found by CPBPs $\mathrm{C}$ and $\mathrm{E}$, and $83 \%$ of criteria were "met fully" or "partially" by CPBPs B and F.

Figure 1 shows the overall frequency of criteria met by each assessment in relation to the evaluated levels. Taking into account the total average of the evaluated criteria, the CPBPs that obtained a larger frequency of criteria met and smaller frequency of criteria not met were, respectively, books $\mathrm{E}(\mathrm{Y}=54 \%$ and $\mathrm{N}=17 \%)$, and book $\mathrm{F}(\mathrm{Y}=37 \%$ and $\mathrm{N}=20 \%)$. In contrast, the CPBP with the lowest performance in the assessments was book $\mathrm{D}$, with $61 \%$ criteria not met.

Table 2 compiles the evaluations issued by participants, showing that agreement among them was not unanimous in any of the 27 criteria assessed, highlighting the following points for each of the three skills (Recognize, Resist and Report): (a) According to the evaluators, two books did not inform about absence of offender stereotypes (A and B), and three did not inform about inexistence of victim stereotypes (A, B and $\mathrm{D}$ ), in terms of the ability to Recognize. Most books (A, B, C, D and E) indicated that offenders could be a trusted person or someone the victim knows fairly well, for only book $\mathrm{F}$ was evaluated as not including such information; (b) with respect to the ability to Resist, the criterion teaching general safety norms was highlighted. According to the evaluations, participants agreed that books B, C and D did not consider such criterion, and in general the remaining books presented such information partially; (c) regarding the ability to Report, the criterion that indicates the relevance of teaching children to identify people who should be trusted is highlighted, and all evaluators agreed that all of books covered this information either completely or partially, except for book A. CPBP E was the only one to clearly stress the importance of notification and reporting child abuse cases, and attention to the child's right to safety. In contrast, all CPBPs avoided graphic scenes of violence or abuse, except according to one evaluator who thought that book D did not avoid such scenes. Concerning the aspect of bringing information and content to support parents and teachers, only books $\mathrm{E}$ and $\mathrm{F}$ fulfilled this criterion.

Evaluators indicated positive and negative aspects of the CPBPs in the open-ended questions: CPBP A was described by Evaluator 1 as a "very long book, containing many difficult to understand words". Evaluator 2 considered that "the use of the word 'hand' to subtly discuss abuse is interesting" allowing the "abuse situation to be revealed gradually". Regarding CPBP $\mathrm{B}$, Evaluator 3 stated that it "is very cryptic and difficult for children to understand". Evaluator 4 pointed out that "the fact that the abuser is a wolf might lead the child to conclude that the offender is a stranger rather than someone with whom the victim is often in contact with". As for CPBP C, Evaluator 5 assessed it as "pleasant, more geared towards young children, but lacking important information to help children protect themselves from sexual abuse". Evaluator 6 concluded that "the text is confusing and presents a Manichaean message" in regards to what is "right and wrong, blending moral values with common sense. There is a make-believe concern in the final text stating that one day there will only exist good touches, and the illustrations are not very attractive for children". For CPBP D, Evaluator 7 affirmed that "the title should be reworded, because despite having the intention of helping children protect themselves from sexual abuse, the topic should be addressed in more detail, providing proper support pertaining to this theme". CPBP E was assessed by Evaluator 8 as "an attractive book for children, providing relevant information without compromising its playful mood". Evaluator 9 considered the same book "as offering relevant and appropriate information to the objectives it pursues". Finally, CPBP F was described by Evaluator 10 as " $f o$ cusing on body anatomy, appealing, easy to un- 
Table 2

Evaluators CCA Responses

\begin{tabular}{|c|c|c|c|c|c|c|c|c|c|c|c|c|c|}
\hline & BOOKS & & A & & B & & $\mathrm{C}$ & & D & $\mathrm{E}$ & & $\mathrm{F}$ & \\
\hline & EVALUATORS & 1 & 2 & 3 & 4 & 5 & 6 & 7 & 8 & 9 & & 111 & 12 \\
\hline \multirow{17}{*}{ 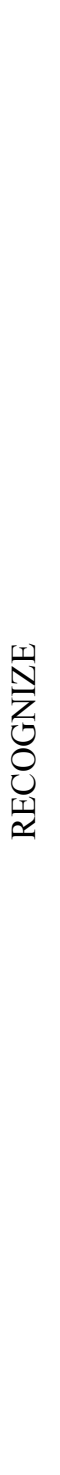 } & Does it present positive models? & $\mathrm{P}$ & $\mathrm{Y}$ & $\mathrm{Y}$ & $\mathrm{P}$ & $\mathrm{P}$ & $\mathrm{P}$ & $\mathrm{Y}$ & $\mathrm{P}$ & Y & $\mathrm{Y} \mathrm{P}$ & $\mathrm{P}$ & Y \\
\hline & Does it teach critical thinking and decision taking skills? & $\mathrm{N}$ & $\mathrm{P}$ & $\mathrm{N}$ & $\mathrm{P}$ & $\mathrm{N}$ & $\mathrm{P}$ & $\mathrm{P}$ & $\mathrm{N}$ & Y & $\mathrm{P} \mathrm{N}$ & $\mathrm{N} \mathrm{I}$ & $\mathrm{P}$ \\
\hline & Does it have characters the readers can identify with? & $\mathrm{Y}$ & $\mathrm{P}$ & $\mathrm{P}$ & $\mathrm{P}$ & $\mathrm{N}$ & $\mathrm{P}$ & $\mathrm{Y}$ & $\mathrm{N}$ & $\mathrm{Y}$ & Y Y & Y & Y \\
\hline & Does it teach about intimate body parts and body anatomy? & $\mathrm{N}$ & $\mathrm{N}$ & $\mathrm{N}$ & $\mathrm{N}$ & $\mathrm{N}$ & $\mathrm{N}$ & $\mathrm{N}$ & $\mathrm{N}$ & $\mathrm{P}$ & $\mathrm{N} \mathrm{Y}$ & Y I & $P$ \\
\hline & $\begin{array}{l}\text { Does it demystify sex and contributes to healthy attitudes } \\
\text { towards sexuality and his or her body? }\end{array}$ & $\mathrm{N}$ & $\mathrm{N}$ & $\mathrm{N}$ & $\mathrm{N}$ & $\mathrm{N}$ & $\mathrm{N}$ & $\mathrm{P}$ & $\mathrm{N}$ & $\mathrm{N}$ & $\mathrm{N} \mathrm{N}$ & $\mathrm{N} \mathrm{I}$ & $\mathrm{P}$ \\
\hline & $\begin{array}{l}\text { Does it provide explicit instructions on body ownership } \\
\text { (my body belongs to me)? }\end{array}$ & $\mathrm{N}$ & $\mathrm{P}$ & $\mathrm{Y}$ & $\mathrm{P}$ & $\mathrm{N}$ & $\mathrm{N}$ & $\mathrm{N}$ & $\mathrm{N}$ & $\mathrm{P}$ & Y Y & Y Y & Y \\
\hline & $\begin{array}{l}\text { Avoids simple solutions which are not useful or realistic, } \\
\text { as there are no happy endings without effort? }\end{array}$ & $\mathrm{Y}$ & $\mathrm{Y}$ & $\mathrm{N}$ & $\mathrm{N}$ & $\mathrm{N}$ & $\mathrm{P}$ & $\mathrm{N}$ & $\mathrm{N}$ & $\mathrm{Y}$ & Y P & P I & $P$ \\
\hline & Does it help to discriminate between good touch and bad touch? & $\mathrm{N}$ & $\mathrm{P}$ & $\mathrm{P}$ & $\mathrm{N}$ & $\mathrm{P}$ & $\mathrm{P}$ & $\mathrm{P}$ & $\mathrm{N}$ & $\mathrm{P}$ & $\mathrm{PS}$ & $S S$ & $\mathrm{~S}$ \\
\hline & $\begin{array}{l}\text { Does it help to discriminate the difference between secrets } \\
\text { and surprises, stressing that some secrets have to be told? }\end{array}$ & $\mathrm{N}$ & $\mathrm{N}$ & $\mathrm{P}$ & $\mathrm{P}$ & $\mathrm{P}$ & $\mathrm{N}$ & $\mathrm{P}$ & $\mathrm{N}$ & $\mathrm{P}$ & $\mathrm{P} N$ & $\mathrm{~N} \mathrm{I}$ & $\mathrm{P}$ \\
\hline & Does it teach that adults sometimes behave inappropriately? & $\mathrm{P}$ & $\mathrm{Y}$ & $\mathrm{P}$ & $\mathrm{N}$ & $\mathrm{Y}$ & $\mathrm{P}$ & Y & $\mathrm{P}$ & Y & Y $\mathrm{P}$ & $\mathrm{P}$ & Y \\
\hline & $\begin{array}{l}\text { Does it differentiate between abusive touching and physical } \\
\text { touch that shows affection? }\end{array}$ & $\mathrm{N}$ & $\mathrm{N}$ & $\mathrm{N}$ & $\mathrm{P}$ & $\mathrm{N}$ & $\mathrm{Y}$ & $\mathrm{P}$ & $\mathrm{N}$ & $\mathrm{N}$ & $\mathrm{N} \mathrm{F}$ & P I & $\mathrm{P}$ \\
\hline & $\begin{array}{l}\text { Does it include information to help readers recognize if they } \\
\text { themselves have been victims of abuse? }\end{array}$ & $\mathrm{P}$ & $\mathrm{P}$ & $\mathrm{N}$ & $\mathrm{P}$ & $\mathrm{P}$ & $\mathrm{N}$ & $\mathrm{N}$ & $\mathrm{N}$ & $\mathrm{P}$ & $\mathrm{Y} \mathrm{F}$ & $\mathrm{P}$ & Y \\
\hline & Is it careful in introducing the offender? & $\mathrm{P}$ & $\mathrm{Y}$ & $\mathrm{P}$ & $\mathrm{N}$ & $\mathrm{P}$ & $\mathrm{P}$ & $\mathrm{N}$ & $\mathrm{N}$ & Y & Y Y & Y I & $P$ \\
\hline & $\begin{array}{l}\text { Does it stress that the inadequate behavior from an adult is } \\
\text { never the child's fault? }\end{array}$ & $\mathrm{N}$ & $\mathrm{P}$ & $\mathrm{N}$ & $\mathrm{N}$ & $\mathrm{P}$ & $\mathrm{N}$ & $\mathrm{Y}$ & $\mathrm{N}$ & $\mathrm{P}$ & $\mathrm{P} N$ & $\mathrm{~N} \mathrm{I}$ & $\mathrm{N}$ \\
\hline & $\begin{array}{l}\text { Does is inform that victims have no stereotype, they may } \\
\text { have any gender, age or ethnicity? }\end{array}$ & $\mathrm{N}$ & $\mathrm{N}$ & $\mathrm{N}$ & $\mathrm{N}$ & $\mathrm{P}$ & $\mathrm{N}$ & $\mathrm{P}$ & $\mathrm{N}$ & $\mathrm{N}$ & $\mathrm{Y} \mathrm{N}$ & $\mathrm{N} \mathrm{I}$ & $\mathrm{P}$ \\
\hline & $\begin{array}{l}\text { Does it inform that there is no offender stereotype, that it } \\
\text { could be a male or female adult, or adolescent? }\end{array}$ & $\mathrm{N}$ & $\mathrm{N}$ & $\mathrm{N}$ & $\mathrm{N}$ & $\mathrm{P}$ & $\mathrm{N}$ & $\mathrm{N}$ & $\mathrm{N}$ & $\mathrm{N}$ & $\mathrm{Y} \mathrm{N}$ & $\mathrm{N} \mathrm{I}$ & $\mathrm{P}$ \\
\hline & $\begin{array}{l}\text { Does it teach that offenders may be people you trust } \\
\text { or people you know? }\end{array}$ & $\mathrm{P}$ & $\mathrm{S}$ & $\mathrm{P}$ & $\mathrm{P}$ & $\mathrm{S}$ & $\mathrm{P}$ & $\mathrm{P}$ & $\mathrm{P}$ & $\mathrm{P}$ & $\mathrm{S} N$ & & $\mathrm{~N}$ \\
\hline
\end{tabular}

Does it teach children general safety rules (address, telephone number, emergency phones?

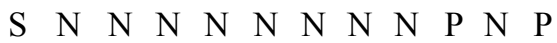

Does it teach the child that he/she can say no and reject unwanted insinuations?

$\begin{array}{llllllllllll}\mathrm{N} & \mathrm{P} & \mathrm{N} & \mathrm{P} & \mathrm{P} & \mathrm{N} & \mathrm{P} & \mathrm{N} & \mathrm{P} & \mathrm{P} & \mathrm{P} & \mathrm{Y}\end{array}$

Does it repeat the safety messages?

$\begin{array}{llllllllllll}\mathrm{N} & \mathrm{P} & \mathrm{N} & \mathrm{N} & \mathrm{P} & \mathrm{N} & \mathrm{N} & \mathrm{N} & \mathrm{P} & \mathrm{N} & \mathrm{P} & \mathrm{Y}\end{array}$

Does it stress that children have the right to be safe?

$\begin{array}{llllllllllll}\mathrm{P} & \mathrm{Y} & \mathrm{N} & \mathrm{Y} & \mathrm{P} & \mathrm{P} & \mathrm{P} & \mathrm{N} & \mathrm{Y} & \mathrm{Y} & \mathrm{P} & \mathrm{Y}\end{array}$

Does it teach children to identify people of trust?

$\begin{array}{llllllllllll}\mathrm{N} & \mathrm{N} & \mathrm{P} & \mathrm{P} & \mathrm{P} & \mathrm{P} & \mathrm{P} & \mathrm{N} & \mathrm{Y} & \mathrm{P} & \mathrm{S} & \mathrm{Y}\end{array}$

Does it encourage the child to tell a trusting adult about things that bother him or her?

$\begin{array}{llllllllllll}\text { P } & P & N & Y & Y & P & Y & P & Y & Y & Y & Y\end{array}$

Does it encourage reporting or case notification?

$\begin{array}{llllllllllll}\mathrm{P} & \mathrm{N} & \mathrm{P} & \mathrm{P} & \mathrm{P} & \mathrm{P} & \mathrm{N} & \mathrm{N} & \mathrm{Y} & \mathrm{Y} & \mathrm{N} & \mathrm{P}\end{array}$ 


$\begin{aligned} & \text { Does it provide opportunity for active participation from the } \\ & \text { child during story reading? }\end{aligned}$
$\begin{aligned} & \text { Does it provide support material for parents and teachers? } \\ & \text { Does it avoid graphic scennes of violence and abuse? }\end{aligned}$

Note. $\mathrm{N}=$ Does not meet criterion; $\mathrm{Y}=$ Meets criterion; $\mathrm{P}=$ Partially meets criterion.

derstand, yet not presenting the reporting issue, or the need not to blame the victim, absence of an offender profile, the issue of secrecy".

\section{Discussion}

Quantitative results resulting from the analysis of evaluator agreement of the present study are considered low by the literature. Landis and Koch (1977) indicate for the agreement between evaluators to be considered high, the Kappa values should be larger than 0.75 , and that a $\mathrm{K}>$ 0.90 result would be a nearly perfect degree of agreement. Results ranging from 0.40 to 0.60 are considered average or fair, such as category $\mathrm{Y}$ for book $\mathrm{E}$ (0.485), and category $\mathrm{N}$ for book A (0.419). The remaining results are considered poor agreement rates, as they present values of $\mathrm{K}<0.40$. Nevertheless, although poor, values of agreement among evaluators of $\mathrm{K}>0$ are superior than those occurring by chance.

Some hypotheses may be raised when using nominal categorical data, as in the present study. Fonseca, Silva and Silva (2007) assert that ratings as the ones from the present study may result from biases, in the sense that they may be related to the evaluators' motivation, their personality, experience in coding, training in using the categories, or even the clarity with which these categories are presented. Although the evaluators were experts in the subject of child sexual abuse, no training in using the specific categories was provided, and these were perhaps not detailed in a way to maximize consensus in the evaluations, which probably impacted on the low kappa results.

Based on the qualitative analysis, according to the evaluators all of the books have the potential of preventing child sexual abuse, as they contain important information to help children protect themselves from this serious problem. Book F, for example, was the only one that attempted to teach the child to clearly discriminate between appropriate and inappropriate touch. This information is crucial, as one of the strategies used by offenders is to portrait the abuse as a fun game, making it difficult for the child to recognize the interaction as abusive (Padilha \& Gomide, 2004; Padilha \& Williams, 2009).

Books A, B, C, D and E presented, either completely or partially, the criterion about informing the child that anyone may be an offender. This is a positive aspect, considering that it is imperative for the child to understand that even persons who are close may display inappropriate behavior that could make children suffer, as the vast majority of abuse occurs within the family (Finkelhor, 1994). While none of the books examined has met all the proposed criteria, book $\mathrm{E}$ achieved the best rating amongst them, according to the data presented in Figure 1 and Tables 1 and 2 .

The fact that one of the authors of the present study is also co-author of one of the evaluated PCPBs could be seen as a limitation of the study. On the other hand, the critical ability of evaluators to make objective assessments should not be minimized. It also should be noted that the analysis here conducted did not intend to rate books as better or worse. The criteria evaluations show that no book received a negative appraisal; therefore, no book may be discarded as not being useful for prevention. Ideally, empirical studies measuring the impact of exposure to a particular book on children would be the final indicator of the utility of a CPBP. Lastly, it should be stressed that the use of books are just auxiliary instruments in child sexual abuse prevention programs, and results are maximized in these interventions if a combination of several strate- 
gies are employed, such as integrating the use of film, music, games with the book of choice (Finkelhor, 2009; Wolfe, 2006). Additionally, it would appear that all books should be followed by learning strategies that meet the literature criteria not yet contemplated its assessment.

\section{Final Considerations}

This study represents a pioneering effort in an the evaluation of children's picture books aimed at sexual abuse prevention, and it may assist professionals working with prevention projects to identify which books meet the objectives the projects aim to develop, thereby increasing the likelihood of children developing protective skills. Additionally, the study may aid researchers in creating and developing new material, or improving existing ones. The study is also relevant to the authors of the analyzed books, providing subsidies that allow them to verify the strengths and weaknesses of each PCPBs, which is an important tool for future revisions of these books or the development of future picture books.

Moreover, it is necessary to take into account that it is not easy to find a book that meets all of the mentioned literature criteria without compromising the attractiveness and creativity of a literary work. Finally, we have verified the need for developing future studies, promoting the evaluation of international PCPBs on child sexual abuse, as well as studies that establish criteria for evaluating books addressing other prevention topics, such bullying, physical violence and neglect, for example.

\section{References}

Alves, H. C., \& Emmel, M. L. G. (2008). Abordagem bioecológica e narrativas orais: Um estudo com crianças vitimizadas [Ecological approach and fairy-tales: A study with child victims]. Paidéia (Ribeirão Preto), 18(39), 85-100. doi:10.1590/ S0103-863X2008000100009.

Arcari, C. (2013). Pipo e Fifi: Prevenção de Violência Sexual na Infância [Pipo and Fifi: Prevention of Child Sexual Violence]. Retrived from http://www.pipoefifi.org.br/home.html

Barros, O. (2011). Segredo Segredíssimo [A Secretive Secret]. São Paulo, SP: Geração Editorial.
Brino, R. F., \& Williams, L. C. A. (2008). Professores como agentes de prevenção de abuso sexual infantile [Teachers as Children Sexual Abuse Prevention Agents]. Revista Educação e Realidade, 33(2), 209-229. Retrived from http://seer. ufrgs.br/index.php/educacaoerealidade/article/ view/7073/4389

Caldin, C. F. (2002). A oralidade e a escritura na literatura infantil: Referencial teórico para a hora do conto [Oral expression and writing in child literature: Theoretical framework to storytelling time]. Revista Eletrônica de Biblioteconomia e Ciência da Informação, 7(13), 25-38. doi:10.5007/1518-2924.2002

Cunha, J. H. S, Gradim, L. C. C., Costa, J. D., Andrade, P. F., Oliveira, N. P., \& Pinto, A. C. (2015). A experiência da Terapia Ocupacional com contação de histórias em uma instituição educacional [Occupational Therapy's experience with storytelling in an educational institution]. Cadernos de Terapia Ocupacional, 23(1), 221-225. Retrived from http://www.cadernosdeterapiaocupacional.ufscar.br/index.php/cadernos/article/viewFile/1235/600

Ferreira, H.M. (2012). Antônio [Anthony]. Rio de Janeiro, RJ: Escrita Fina.

Finkelhor, D. (1991). Child sexual abuse. In M. L. Rosenberg \& M. A. Fenley, Violence in America: A public Health Approach (pp. 79-94). New York: Oxford University Press.

Finkelhor, D. (1994). The international epidemiology of child sexual abuse. Child Abuse \& Neglect, 18, 409-417. doi:10.1016/01452134(94)90026-4.

Finkelhor, D. (2009). The prevention of childhood sexual abuse. The Future of Children, 19(2), 169-194. Retrived from http://futureofchildren.org/futureofchildren/publications/ docs/19_02_08.pdf

Fonseca, V. (2008). A invasão do planeta chamado Carinho [The invasion of a planet named Affection]. São Paulo, SP: All Print.

Fonseca, R., Silva, P., \& Silva, R. (2007). Acordo inter-juízes: O caso do coeficiente kappa [Interrater agreement: The kappa coefficient]. Laboratório de Psicologia, 5(1), 81-90. Retrived from http://hdl.handle.net/10400.12/1263

Kenny, M. C., \& Wurtele, S. K. (2010). Children's abilities to recognize a "good" person as a potential perpetrator of childhood sexual abuse. Child Abuse \& Neglect, 34, 490-495. doi:10.1016/j. chiabu.2009.11.007 
Kraska-Miller, M. (2008). Nonparametric Statistics for the Behavioral Sciences. Alabama: Alburn University.

Lampert, J. (2011). Sh-h-h-h: Representations of perpetrators of sexual child abuse in picture books. Sex Education: Sexuality, Society and Learning, 12(2), 177-185. doi:10.1080/14681811.2011.60 9048

Lampert, J., \& Walsh, K. (2010). 'Keep telling them until someone listens': Understanding prevention concepts in children's picture books dealing with child sexual abuse. Children's Literature in Education, 41(2), 146-167. doi:10.1007/s10583010-9104-1

Landis, J. R., \& Koch, G. G. (1977). The measurement of observer agreement for categorical data. Biometrics, 33(1), 159-174. doi:10.2307/2529310

McDaniel, C. (2001). Children's literature as prevention of child sexual abuse. Children's Literature in Education, 32(3), 203-224. doi:10.1023/A:1010402202633

Padilha, M. G., \& Gomide, P. I. C. (2004). Descrição de um processo terapêutico em grupo para adolescentes vítimas de abuso sexual [A therapeutic group process with sexually abused female adolescents]. Estudos de Psicologia (Natal), 9(1), 53-61. doi:10.1590/S1413294X2004000100007

Padilha, M. G., \& Williams, L. C. (2009). Intervenção escolar para prevenção do abuso sexual com estudantes pré-adolescentes e adolescentes [School intervention for the prevention of sexual abuse with pre-adolescents and adolescents]. In L. C. A. Williams \& E. A. Araújo, Prevenção ao Abuso Sexual Infantil: Um Enfoque Interdisciplinar [Prevention of Child Sexual Abuse: An interdisciplinary approach] (128-135). Curitiba, PR: Juruá.

Silva, A. R. S., Soma, S. M. P., \& Watarai, C. F. (2011). O segredo da Tartanina: Um livro a Serviço da Proteção e Prevenção contra o Abuso Sexual Infanto-Juvenil [Tartanina's secret: A book towards the Protection and Prevention of Child Sexual Abuse]. Pompéia, SP: Centro Universitário do Distrito Federal.

Siquinel, C. B. (2010). Chapeuzinho Cor-de-Rosa e a astúcia do Lobo Mau [Little Pink Riding Hood and the Big Bad Woolf's shrewdness]. Rio de Janeiro, RJ: LITTRIS.

Soma, S. M. P., \& Williams, L. C. A. (2014). Livros infantis para prevenção do abuso sexual infantil:
Uma revisão de estudos [Children's books for the prevention of child sexual abuse: A review of studies]. Temas em Psicologia, 22(2), 353361. doi:10.9788/TP2014.2-07

Souto-Maior, S. D. (2000). O mapa do tesouro: U1trapassando obstáculos e seguindo pistas no cotidiano da educação infantil [The treasure map: Overcoming obstacles and following clues in daily children's education]. In L. E. Ostetto (Ed.), Encontros e encantamentos na educação infantil [Encounters and enchantment in children's education] (pp. 63-82). São Paulo, SP: Papirus.

Souza, L. O., \& Bernardino, A. D. (2011). A contação de histórias como estratégia pedagógica na educação infantil e ensino fundamental [Storytelling as a pedagogical strategy in early education and elementary school teaching] Revista de Educação, 6(12), 235-249. Retrived from http:// revista.unioeste.br/index.php/educereeteducare/ article/download/4643/4891

Vélez, C. M., Henao, P. A., Ordoñes, F., \& Gómez, L. E. (2015). Evaluación de un programa de promoción de conductas de autoprotección para la prevención del abuso sexual infantil, Medellín, Colombia [Evaluation of a self-protection behavior promotion programme to the prevention of child sexual abuse, Medellin, Colombia]. Revista Médica Risaralda, 21(1), 3-8. Retrived from http://revistas.utp.edu.co/index.php/revistamedica/article/view/8855

Wolfe, V. V. (2006). Child sexual abuse. In E. J. Mash \& R. A. Barkley (Eds.), Treatment of Childhood Disorders (pp. 545-597). New York: The Guilford Press.

Wurtele, S. K. (2008). Behavioral approaches to educating young children and their parents about child sexual abuse prevention. The Journal of Behavior Analysis of Offender and Victim Treatment and Prevention, 1(1), 52-64. doi:10.1037/ h0100434

Zak, P. (2013). How stories change the brain. Greater Good: The science of a Meaningful Life. Retrived from http://greatergood.berkeley.edu/article/item/how_stories_change_brain 